\title{
DISTRIBUTION, STRUCTURAL CONTROLS AND AGES OF KIMBERLITE FIELDS IN THE SUPERIOR PROVINCE OF QUEBEC.
}

\author{
James Moorhead (1*), Marc Beaumier (2), Réjean Girard (3) and Larry Heaman (4)
}

(1) Ministère des Ressources naturelles, Québec, 400 boul. Lamaque, Val-d'Or, Qué. J9P 3L4

(2) Ministère des Ressources naturelles, Québec, $57004^{\mathrm{e}}$ avenue ouest, local A-206, Charlesbourg, Qué.G1H 6R1

(3) IOS, 3312, boul. St-Francois, Jonquière, Québec, G7X 2W9

(4) Dept. Of Earth and Atmospheric Sciences, University of Alberta, Edmonton, Alberta, T6G 2E3

\section{Introduction}

The Canadian Superior Province is one of the largest Archean cratons in the world, half of which is located in Quebec. So far, approximately 60 pipes and numerous dykes, distributed in 7 distinct fields (Wawa, Missisa, Attawapiskat, Témiscamingue, Desmaraisville, Otish and Wemindji, have been discovered. This is quite small when compared to the 100's of pipes identified so far in the much smaller Slave Province or the 1000's of occurrences known in South Africa. We have compiled the kimberlite occurrences of Quebec along with their main structural controls in order to assess areas in the $\mathrm{E}$ Superior Province that may host new kimberlite fields. In addition we present a new $\mathrm{U}-\mathrm{Pb}$ age for a kimberlite pipe in the Otish Field.

\section{Kimberlites of Quebec}

Five kimberlite fields are recognized in Quebec; they include the Temiscamingue, Desmaraisville, Otish, Wemindji and Torngat fields (Fig. 1).

\section{Temiscamingue field (KTE)}

The Temiscamingue field (KTE) is located within the Pontiac and Abitibi Sub-Provinces, near the Quebec/Ontario border. It lies within the Lake Temiscaming Structural Zone (TZ) which is defined by Brummer et al. (1992) as a 150-200 km wide structure oriented to the NW at $327^{\circ}$ that extends for close to 1000 $\mathrm{km}$ from the Hudson Bay Lowlands to the State of New York. The south eastern portion of the field, located in Quebec, lies within the Cobalt sector (SCO) (Sage, 1996). In this area the main structural feature is the NW trending Paleozoic Lake Temiscaming rift zone. In Quebec, it contains 6 weakly diamondiferous diatreme and hypabyssal facies kimberlite pipes, identified as the Guigues, BT-44 and Notre-Dame du Nord-1a, b, c \& 2 pipes. The Guigues and Notre-Dame du Nord-1a pipes have been dated respectively at $142.3+/-6.6 \mathrm{Ma}$ (perovskite, U-Pb) and $125+/-1 \mathrm{Ma}$ (phlogopite, Rb-Sr), (Sage, 1996; Heaman and Kjarsgaard, 2000).

\section{Desmaraisville field (KDE)}

The Desmaraisville field (KDE) is located in the north-central portion of the Abitibi Sub-Province. It lies within the Waswanipi-Saguenay Tectonic Zone (WSZ) which is defined by the NW projection $\left(286^{\circ}\right)$ of the Early
Paleozoic Saguenay rift zone trough the Grenville Province to the James Bay Lowlands. In the north-central portion of the Abitibi Sub-Province, it is defined by late WNW faults that displace early Proterozoic dykes and encompasses a small basin of Ordovician age carbonates and Archean age carbonatite intrusions. The field is subdivided into 2 sectors; Le Tac (SLT) and Ailly (SAI). The Le Tac sector contains 3 very weakly diamondiferous hypabyssal facies pipes and numerous dykes that are located in close proximity to NE trending diabase dykes of the Preissac swarm (2167-2214 Ma). Two of the kimberlitic dykes were dated at $1100 \mathrm{Ma}$ (phlogopite, KAr; Watson, 1967) and 1104 +/- 17 Ma (phlogopite, RbSr; Alibert and Albarede, 1988). The Ailly Sector is located $45 \mathrm{~km}$ to the NW contains 2 hypabyssal facies pipes and a few dykes that are in close proximity to an extensive ENE trending diabase dyke that belongs to the Abitibi Swarm (1141 Ma). Only one microdiamond was reported from one pipe. It seems that the main structural control for the field is the NW trending WSZ, but NE trending faults and diabase dykes seem to control the location of individual pipes and dykes.

\section{Otish field (KOT)}

The Otish field (KOT) is located in the NE part of the Opatica and Opinaca Sub-Provinces, to the north and west of the Proterozoic Otish basin. It comprises two distinct sectors, the first (a) centred on Lac Beaver (Ditem Explorations) and the second (b) covering the Renard (SOQUEM/Ashton Mining of Canada) and Portage (Majescor Resources/BHP Billiton Diamonds) properties. Both sectors are located at the southern end of the Mistassini-Lemoyne Tectonic Zone (MLZ), which extends $650 \mathrm{~km}$ ENE $\left(25^{0}\right)$ from the Mistassini Basin to the Labrador Trough. This zone is defined by a series of NNE-trending $\left(20-30^{\circ}\right)$ lineaments and faults which form a dominant network in the western part of the Ashuanipi Sub-Province and easternmost portion of the La Grande (Portella, 1980; Thériault and Chevé, 2001). From the south northward, the MLZ, hosts late Proterozoic (551 Ma) kimberlites in the Otish field, Archean syenites of the Niaux Suite, exploration properties held by SOQUEM/Ashton to the west of the Caniapiscau Reservoir and in the Lac Gayot area, and the Early Proterozoic Lac Castignon (1880 Ma) and Lac Lemoyne $(<1870 \mathrm{Ma})$ carbonatites located in the Labrador Trough. 
The MLZ could mark a highly permeable zone to alkaline magmatism, similar and at a weak angle to the Kapuskasing tectonic zone in Ontario (Portella, 1980; Moorhead and al., 1999). The MLZ is thought to be the major structural feature for the Otish Field. There are numerous NW trending late faults and diabase dykes in the area of the Otish Field. The NW trending diabase dykes belong to the $2475 \mathrm{Ma}$ Mistassini Swarm. There is also an extensive NE trending diabase dyke, belonging to the Preissac Swarm (2167 Ma).

In our initial study (Moorhead et al., 1999, 2000) we had identified the NE portion of the Mistassini Dykes as the ill-defined NW trending Témiscamie-Corvette Tectonic Zone (Fig. 3), which includes NW trending subparallel faults and the cratonic arch between the Mistassini and Otish Basins. The NNE trending faults were thought to be secondary transverse faults. From recent mapping projects and kimberlite discoveries it would be more accurate to present the NNE trending features, now the MLZ, as the dominant structural control and the NW trending ones as secondary. It is interesting to note the Renard kimberlite pipes of SOQUEM/Ashton are aligned parallel to the NW parallel to the local Mistassini diabase dykes.

\section{a) Lac Beaver sector (SLB)}

The Lac Beaver sector is located near the NW margin of the Otish basin. It contains a kimberlite dyke swarm and an adjacent weakly diamondiferous hypabyssal pipe (Brack, 1999). The pipe was dated at $550.9+/-3.5 \mathrm{Ma}$ (perovskite, U-Pb; this study). This age is quite similar to the alkaline intrusions of the Saguenay rift zone to the south in the Grenville Province, which marks the continental rifting of the southern margin of Laurentia and the opening of the Iapetus ocean. In 1997, Ditem Explorations recovered 4 macrodiamonds by caustic dissolution, from drill samples totalling $511 \mathrm{~kg}$. No diamonds (>0.8 mm) were recovered from a 6 tonne bulk sample (Brack, 1999). The Lac Beaver hypabyssal pipe shows typical late calcite-serpentine segregations (Bernier and Moorhead, 2000) and contains a high proportion $(25 \%)$ of harzburgitic garnets $(\mathrm{G} 10)$ relative to lherzolitic garnets (G9) (Girard, 2001). The G10 garnets have $\mathrm{Cr} 2 \mathrm{O} 3$ contents ranging from 5 to $7 \%$. Furthermore, the chemistry of chromites is very close to diamond inclusion field (Girard, 2001). In 2002, approximately $20 \mathrm{~km} \mathrm{~N}$ of the Lac Beaver kimberlite, Ditem Explorations and Pure Gold announced the discovery of a two breccias, $\mathrm{H} 1$ and $\mathrm{H} 2$, with lithological characteristics compatible with kimberlite. One microdiamond was recovered from a $23.15 \mathrm{~kg}$ core sample.

\section{b) Renard sector (SRE)}

In a restricted zone located about $90 \mathrm{~km}$ north of the Lac Beaver kimberlite, SOQUEM/Ashton Mining has uncovered a cluster of 8 small hypabyssal facies kimberlitic bodies. So far, all of the pipes are diamondiferous (Ashton, press releases, 2002-03); a 2.44 ton sample from the Renard 2 pipe contained 1.69 carats (diamonds $>0.85 \mathrm{~mm}$; $69 \mathrm{ct} / \mathrm{ht}$ ), a 4.88 ton sample from the Renard 3 pipe contained 6.54 carats (diamonds $>0.85$ $\mathrm{mm} ; 134 \mathrm{ct} / \mathrm{ht}$ ), a 4.81 ton sample from the Renard 4 pipe contained 3.11 carats (diamonds $>0.85 \mathrm{~mm}$; $65 \mathrm{ct} / \mathrm{ht}$ ).

Exploring in the same sector, Majescor Resources/BHP Billiton Diamonds acquired a large property, known as Portage, that borders the SOQUEM/Ashton property to the SW and NE. A sampling program for indicator minerals and an airborne geophysical survey were carried out. This sector contains an important proportion of G10-type garnets (20\% G10/G9) with high $\mathrm{Cr}_{2} \mathrm{O}_{3}$ values (7-13\%). So far, no kimberlite discoveries have been reported.

\section{Wemindji field (KWE)}

The area lying between the town of Wemindji on the east coast of James Bay and the LG2 Réservoir Robert-Bourassa is located in the La Grande Subprovince, in the western part of the Wemindji-Caniapiscau structural zone (WCZ) that extends in an ENE direction at $70^{\circ}$ from Wemindji to the Labrador Trough near Schefferville (Moorhead and al., 1999). This tectonic zone is defined by a series of sub-parallel late en-échelon faults that follow the La Grande River to the Caniapiscau Reservoir in the eastern portion of the craton. The central portion of the WCZ contains 7 ENE trending graben type basins that are infilled by the $2.2 \mathrm{Ga}$ old siliciclastic succession of the Sakami Formation.

This area immediately to the east of Wemindji had been the focus of an exploration program by Monopros, who identified a $32 \mathrm{~km}$ long KIM dispersal train. Nine aeromagnetic anomalies were drilled but no kimberlites were intersected (Pomares, 1998). In 2002, Majescor Resources announced that a drill campaign intersected sub-horizontal kimberlite sills averaging $2 \mathrm{~m}$ in thickness. 8.5 tonnes of kimberlite were excavated from one of the sills. No diamonds larger than $0.8 \mathrm{~mm}$ were recovered from this sample. A caustic fusion analysis done on a $190 \mathrm{~kg}$ sample from this sill yielded 2 microdiamonds (Majescor Resources, press release).

In an area south of the LG2 Réservoir, east of the Wemindji kimberlites, a few samples of mafic lamprophyre dykes contain microdiamonds. According to Dianor Resources, these dykes have some geochemical and mineralogical similarities with the diamond bearing lamprophyres of the Wawa area.

\section{Torngat field (KMT)}

Diamond-bearing dykes were recently recognized in the Alluviaq (Abloviak) Fjord area, in the Monts Torngat, along the east coast of Ungava Bay. This area lies in the eastern portion of the Paleoproterozoic Rae Province, near the Archean Nain craton further east. Digonnet et al. (2000) classified the dykes as carbonatized 
ultramafic lamprophyres, which show features similar to aillikites and group-2 kimberlites (orangeites). These dykes were dated at $550 \mathrm{Ma}$ (Ar-Ar, phlogopite).

Twin Mining has been exploring and sampling these dykes since 1999. Their work culminated with the extraction, from the Torngat-1 dyke, of 3 bulk samples totalling 342 tonnes, from which 1,548 macrodiamonds $(>1 \mathrm{~mm})$, for a total weight of 13.12 carats, were recovered (3.8 ct/ht). Further east along Alluviaq Fjord, Tandem Resources/Diamond Discoveries International, discovered additional dykes, some of which are diamondiferous.

\section{Exploration targets in the northern Superior Province}

In many cases, kimberlites found in archean cratons are localized along large lineaments or fault zones (White et al., 1995; Kaminski et al., 1995) and are, in some cases, located near other types of alkaline intrusions (Dawson, 1964). Some kimberlite fields are situated near intersections of cross-structures with the main lineament or fault zone (White et al., 1995). We have compiled syenites, generally nepheline bearing, carbonatites, kimberlites and other alkaline intrusions in Quebec as well as the main large linear brittle structural zones, locally defined by late faults, aeromagnetic and remote sensing lineaments, and graben type sedimentary basins (Fig. 1; Moorhead et al., 1999).

Globally, the distances between many of the large kimberlite fields are in the order of $400 \mathrm{~km}$, although in some cases they may be much less (Janse, 1993). The average distance between kimberlite fields of the Canadian Shield was approximately $470 \mathrm{~km}$ in 1998 (Fig. 2; Moorhead et al., 1999), with the discoveries in Wemindji and the Otish areas this average is now closer to $400 \mathrm{~km}$. The distances between some fields are significantly higher or lower, nevertheless the value of $470 \mathrm{~km}$ maybe useful as a general approximation for the location of yet undiscovered kimberlite fields. By extrapolating a distance of $470 \mathrm{~km}$ from known kimberlite fields and using the position of large brittle linear structural zones and their cross- faults, 4 new areas of interest for diamond exploration were defined in northern Quebec and 1 in Ontario (Moorhead et al., 1999; Fig. 3):

1- The area between the village of Wemindji and the LG2 hydroelectric reservoir dam is located at the western end of the WCZ. This area is located at roughly the same distance of $400 \mathrm{~km}$ from the three adjacent kimberlite fields; Attawapiskat, Desmaraisville and Otish. It also lies on the NE projection of the Kapuskasing Tectonic Zone. In 2002, kimberlite sills have been discovered in this area by Majescor Resources, $75 \mathrm{~km}$ further east Dianor Resources discovered diamond bearing mafic lamprophyre dykes.

2- The westernmost portion of the Ashuanipi Province, adjacent to the Caniapiscau Reservoir, in the eastern part of the WCZ is crosscut by numerous NNE trending faults of the MLZ and contains several nepheline syenite intrusions (Thériault and Chevé, 2000). This area where the MLZ and the WCZ intersect is located roughly $300 \mathrm{~km}$ to the NNE of the Beaver Lake Pipe of the Otish Field. A large block of claims were acquired in this area by SOQUEM/Ashton, they refer to these claims as the Taiga project.

3- The area to the $\mathrm{N}$ of Bienville lake, near the western portion of the Saindon-Cambrien structural zone (SCZ), which extends from Cambrian lake in the south-central portion of the Labrador Trough, WSW at $250^{\circ}$, to the middle of the Superior craton. This tectonic zone is defined by faults, lineaments and graben style basins that are nearly identical to those of the WCZ to the south. This area also lies on the NE projection of the Kapuskasing tectonic zone and is located approximately $420 \mathrm{~km} \mathrm{NNW}$ of the Beaver Lake Pipe of the Otish Field and approximately 470 $\mathrm{km}$ to the NE of the Wemindji sills.

4- The area adjacent to Tasiat lake in the ill-defined ATZ, which extends from Allemand lake in the southcentral portion of the Ungava Trough SSE to the center of Ungava peninsula. This area would be 470 $\mathrm{km}$ north of area 3.

5- The Western Superior Province is also devoid of kimberlites. The area to the west of Lake Nipigon could be of interest since it lies at roughly $470 \mathrm{~km}$ from the three adjacent kimberlite fields (Attawapiskat, Wawa and Lake Ellen). It is located to the west of the Coldwell Alkaline Province.

\section{Discussion}

The northern portion of the Superior Province in Quebec represents an attractive area for diamond exploration. Noteworthy features include the presence of well defined large-scale brittle fault zones (MLZ, WCZ, SCZ, RGZ), locally hosting alkaline intrusions, and the NE projection of the Kapuskasing structural zone into northern Quebec. This projection corresponds to a zone where orientations of main lineaments change from a WSW direction, in the central part of the craton (i.e. the $\mathrm{SCZ}$ ), to a NW direction on its western margin (i.e. the RGZ)(Portella, 1980). It also encompasses kimberlite sills near Wemindji (Majescor Resources, 2002) and diamond bearing lamprophyre dykes (Dianor Resources, 2002). Curiously, tracing the Kapuskasing tectonic zone further to the NE would intersect approximately the diamondiferous lamprophyre dykes located in Alluviaq Fjord, adjacent to the Monts Torngat.

The 4 kimberlite fields of the Superior Province in Quebec are located within extensive structural zones that are defined by series of regional scale sub-parallel late faults. These zones are readily recognisable on satellite images and regional geological, aeromagnetic and shaded relief maps. Some of these structural zones contain Paleozoic (TZ, WSZ) and Proterozoic rift basins (WCZ, 
SCZ, RGZ). It is important to note that many of these structural zones were described in other studies unrelated to kimberlites (ie Portella, 1980). Most of the zones contain Proterozoic or Archean alkaline intrusions. Kimberlites in the Otish and Desmaraisville fields are also located very near $2^{\text {nd }}$ order structures such as late crossfaults or Proterozoic diabase dykes.

Since our study in 1998-1999, new kimberlite discoveries have been made in N Quebec within the WCZ (sills near Wemindji, Majescor Resources, 2002) and the MLZ (the Renard cluster of pipes in the Otish area, SOQUEM/Ashton, 2001). In addition, new zones of anomalous KIM have been outlined in some structural zones (Fig. 1):

- The Nottaway Zone (NZ) near James Bay by Poplar

Resources in 2001.

- The WSZ, $120 \mathrm{~km}$ west of the Desmaraisville field by Globestar Mining Corporation in 2002.

- The MLZ, $320 \mathrm{~km}$ NNE of the Renard cluster in the Gayot Lake area by Majescor Resources/Diamondex Resources in 2002.

Existing kimberlites and these new discoveries seem to underline the importance of defining large scale structural zones of late, mostly brittle, faults and their secondary transverse structures as an exploration guide for new kimberlite fields or clusters. The Wemindji sills are an example of the use of extrapolating a 400-470 km distance from known kimberlites. However the Renard cluster and many of the KIM zones are located much closer to known clusters and fields. We believe that the structural zones in Fig. 1 have the potential to host more kimberlites.

\section{REFERENCES}

ASHTON MINING OF CANADA, 2000-2003. Press releases.

ALIBERT, C. and ALBAREDE, F., 1988. Relationships between mineralogical, chemical and isotopic properties of some North American kimberlites. Journal of Geophysical Research, vol. 93, no. B7, p. 7643-7671.

BERNIER, L. and MOORHEAD, J., 2000. Étude pétrographique et minéralogique de la kimberlite des monts Otish. Ministère des Ressources naturelles, Québec. MB 2000-14, 55 pages.

BRACK, W., 1999. Report on the diamond drilling activities in 1998, Otish Mountains Project, DITEM Explorations Inc. Ministère des Ressources naturelles, Québec. GM 56615, 116 pages.

BRUMMER, J.J., MacFAYDEN, D.A. and PEGG, C.C., 1992. Discovery of Kimberlites in the Kirkland Lake Area, Northern Ontario, Canada. PART II: Kimberlite Discoveries, Sampling, Diamond Content, Ages and Emplacement. Journal of Exploration and Mining Geology, vol. 1, No. 4, p. 351-370.

DAWSON, J.B., 1964. An aide to prospecting for kimberlites. Economic Geology, Scientific Communications, vol. 59, p. $1385-1386$

DIGONNET, S., GOULET, N., BOURNE, J., STEVENSON, R. and ARCHIBALD, D., 2000. Petrology of the Abloviak Aillikite Dykes, New Québec : evidence for a Cambrian diamondiferous alkaline province in northeastern North America. Canadian Journal of Earth Sciences, vol. 37, p. 517533.

DITEM EXPLORATIONS INC., 1996-2002. Press releases.

GIRARD, R., 2001. Caractérisation de l'intrusion kimberlitique du lac Beaver, Monts Otish, pétrographie et minéralogie. Ministère des Ressources naturelles, Québec. MB 2001-08, 82 pages.

HEAMAN, L.M. and KJARSGAARD, B.A., 2000. Timing of eastern North American kimberlite magmatism: continental extension of the Great Meteor hotspot track? Earth and Planetary Sciences Letters, vol. 178, p. 253-268.

HOCQ, M., 1994. La Province du Supérieur. Dans: Géologie du Québec, Ministère des Ressources naturelles, Québec, MM 9401, p. 7-20.

JANSE, A.J.A., 1993. The aims and economic parameters of diamond exploration. In : Diamonds : Exploration, Sampling and Evaluation. Proceedings of a short course presented by the Prospectors and Developers Ass. of Canada, p. 173-184.

KAMINSKY, F.V., FELDMAN, A.A., VARLAMOV, V.A., BOYKO, A.N., OLOFINSKY, L.N., SHOFMAN, I.L. and VAGANOV, V.I., 1995. Prognostication of primary diamond deposits. Journal of Geochemical Expl., vol. 53, p. 167-182.

MOORHEAD, J., BEAUMIER, M., LEFEVBRE, D., BERNIER, L. and MARTEL, D., 1999. Kimberlites, linéaments et rifts crustaux au Québec. Ministère des Ressources naturelles, Québec. MB 99-35, 113 pages.

MOORHEAD, J., PERREAULT, S. , BERCLAZ, A., SHARMA, K.N.M., BEAUMIER, M. and CADIEUX, A.M., 2000. Kimberlites and diamonds in Northern Quebec. Ministère des Ressources naturelles, Québec. PRO 99-09, 11 pages.

POMARES, J.S., 1998. Monopros Limited, Assessment report on the drilling campaign over the exploration permit 0001295, Wemindji area, Quebec. Ministère des Ressources naturelles, Québec. GM 56048, 43 pages.

PORTELLA, P., 1980. Les bassins sédimentaires protérozoïques du lac Tilly et de la rivière Laforge. Leur place dans l'agencement structural du territoire du Nouveau-Québec dégagé par photographies de satellites et cartes aéromagnétiques. Thèse de doctorat, Université scientifique et médicale de Grenoble, 197 pages.

SAGE, R.P., 1996. Kimberlites of the Lake Timiskaming Structural Zone. Ontario Geological Survey, Open File Report 5937, 435 pages.

THÉRIAULT, R. and CHEVÉ, S., 2001. Géologie de la région du Lac Hurault (SNRC 23L). Ministère des ressources naturelles, Québec, RG 2000-11, 49 pages.

TWIN MINING CORPORATION, 2000-2002. Press releases.

WATSON, R.D., 1967. Kimberlites of Eastern North America. In: Ultramafic and related rocks. Edited by P.J. Wylie. John Wiley and Sons, New York, vol. 9, p. 312-323.

WHITE, S.H., BOORDER, H., and SMITH, C.B., 1995. Structural controls of kimberlite and lamproite emplacement. Journal of Geochemical Exploration, vol. 53, p. 245-264.

(1*) Ministère des Ressources naturelles, Québec, 400 boul. Lamaque, Val-d'Or, Qué. J9P 3L4

tel: (819) 354-4735, ext. 242, email: james.moorhead@mrn.gouv.qc.ca 

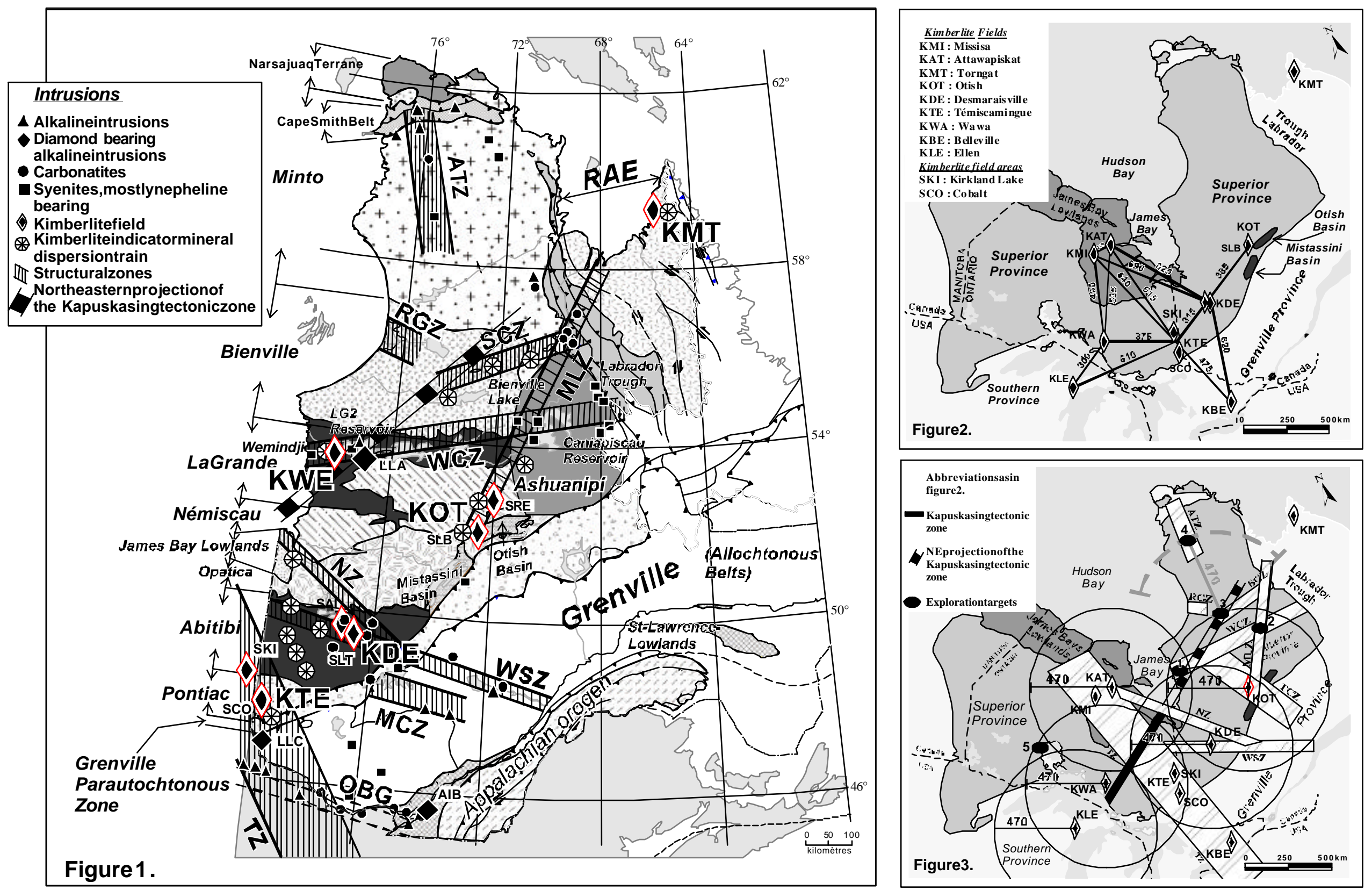

Figure1.Tectonicsub-divisionsofQuebec(Hocq,1994)withthelocationoflarge-scalebrittlefaultzonesandalkalineintrusions. Structuralzones:ATZ:Allemand-TasiatZone,RGZ:RichmondGulfZone, SCZ: Saindon-CambrianZone,MLZ:Mistassini-LemoyneZone, WCZ: Wemindii-CaniapiscauZone,TCZ:Témiscamie-Corvette Zone, NZ:NottawayZone,WSZ:Waswanipi-SaguenayZone,MCZ: Mégiscane-ChasseurZone,TZ:TemiscamingueZone,OBG:Ottawa-BonnechereGraben.KimberliteFields: Torngat(KMT);Wemindji(KWE); Otish (KOT)(SRE:RenardSector,SLBBeaverLakeSector );Desmaraisville(KDE)(SLT:LeTacSector,SAl:AillySector);Témiscamingue(KTE)(SCO:CobaltSector,SKI:KirklandLakeSector).Diamondbearingalkalineintrusions:IleBizzardAlnoïtes(AIB), CampeauTownshipultramaficlamprophyres(LLC),MaficlamprophyresofLacdel'Astrée(LLA).

Figure2:KimberlitefieldsoftheCanadianShield, withdistancesinkilometers. Figure3Kimberlitefields,structuralzones, theKapuskasingtectoniczonewithits NEprojectionandcircleswitha470km radiuscenteredonthethreemostnortherlyandwesterlykimberlitefieldsoftheSuperiorProvince. Intersectionareas $(1-5)$ betweenthecirclesandthebrittlestructuralzonesmayrepresentareasfor diamondexploration. 